\title{
Modification of mucin clots by serum
}

\author{
J. R. E. FRASER AND G. S. HARRIS
}

From the University of Melbourne Department of Medicine, the Royal Melbourne Hospital, Victoria, Australia

Mucin clots formed from synovial fluid by addition of acetic acid are typically compact and cohesive, with a clear supernatant. After treatment with hyaluronidase, acidification of synovial fluid produces fragile granular precipitates, turbidity, opalescence, or no change at all, according to the extent to which prior depolymerization of the hyaluronic acid is allowed to proceed (Robertson, Ropes, and Bauer, 1940; Ogston and Stanier, 1953). Similar effects follow non-enzymic breakdown of hyaluronic acid, or increasing salt concentrations.

The present report describes and analyses radical changes in mucin complexes induced solely by the presence of fresh serum prepared from peripheral blood. These changes were first found incidentally when synovial cell cultures were grown in the presence of fresh or heat-inactivated serum (Clarris and Fraser, 1968). Mucin clots could be precipitated in all the culture media containing heat-inactivated serum but were consistently absent or much smaller in the paired media containing fresh serum. Cell numbers, cell growth rates, and the hyaluronic acid concentrations were similar in each paired study (Fraser, Harris, and Clarris, 1969), and it was later found that the deficiencies in mucin clots in the fresh-serum media could be restored by heatinactivation before acidification. It was thus clear that fresh serum did not reduce the amount of hyaluronic acid formed or greatly alter its polymerization during or after secretion. Similar differences in clots were then reproduced from mixtures of fresh or heat-inactivated serum with hyaluronic acid prepared direct from synovial fluid.

Although mucin complexes are artefacts of acid conditions, the first stage in their formation is one of a class of protein-polysaccharide combination which might be related to those found in physiological conditions (Ogston and Stanier, 1950). Moreover, the abnormal mucin clots of synovial fluid from inflamed joints have long been a matter of theoretical interest. The above-mentioned reaction between fresh serum and hyaluronic acid was therefore examined further in vitro.

\section{Material and methods}

These were identical with those given in a previous paper (Harris and Fraser, 1971) with the following additions:

HUMAN SERUM was prepared from fasting normal subjects, with care to avoid denaturation. One part of each sample was heat-inactivated at $56^{\circ} \mathrm{C}$. for $30 \mathrm{~min}$. in sealed rubber-capped vials, and the other part was either chilled or held at room temperature until used.

PRECIPITATION OF HYALURONIC ACID in mucin complexes was compared in each instance with the same preparation of hyaluronic acid, and with fresh and heat-inactivated aliquots from a single sample of serum. The reaction was usually performed with the components at room temperature or at $4^{\circ} \mathrm{C}$. Additional reagents used were chondroitin sulphate ex bovine nasal cartilage (Sigma, U.S.A.) and heparin (C.S.L., Melbourne).

Table I Recovery of hyaluronic acid from fresh and heated serum

\begin{tabular}{|c|c|c|c|c|c|}
\hline \multirow{3}{*}{$\begin{array}{l}\text { Hyaluronic } \\
\text { acid added } \\
(\mu g .)\end{array}$} & \multirow{3}{*}{$\begin{array}{l}\text { Serum } \\
\text { concentration } \\
\text { (per cent. v/v) }\end{array}$} & \multicolumn{4}{|c|}{ Hyaluronic acid recovered from mucin complex ( $\mu g)}$. \\
\hline & & \multicolumn{2}{|c|}{ (a) With heat-inactivated serum } & \multicolumn{2}{|c|}{ (b) From fresh serum } \\
\hline & & Mean & S.D. & Mean & S.D. \\
\hline $\begin{array}{l}28 \cdot 0 \\
20 \cdot 2 \\
21 \cdot 2\end{array}$ & $\begin{array}{l}25 \\
50 \\
50\end{array}$ & $\begin{array}{l}28 \cdot 0 \\
20 \cdot 7 \\
21 \cdot 7\end{array}$ & $\begin{array}{l}0 \cdot 73^{*} \\
0 \cdot 41 * \\
0 \cdot 36 \dagger\end{array}$ & $\begin{array}{l}3 \cdot 6 \\
2 \cdot 8 \\
3 \cdot 1\end{array}$ & $\begin{array}{l}0 \cdot 4^{*} \\
0 \cdot 84^{*} \\
0.79 \dagger\end{array}$ \\
\hline
\end{tabular}

$n=6$.

$t_{n}=3$. 


\section{Results}

QUANTITATIVE RECOVERY OF HYALURONIC ACID IN PRECIPITATED MUCIN COMPLEXES

Mucin complexes were first formed in mixtures similar in content to cell-culture medium. Precipitation of the hyaluronic acid was complete with heatinactivated serum, but grossly deficient with fresh serum (Table I). The measured differences corresponded with the appearances of the mucin complexes which were either smaller or absent in the presence of fresh serum, although a few micrograms of hyaluronic acid present as a turbidity could be separated by centrifugation.

Experiments were conducted with different proportions of heat-inactivated and fresh serum (Table II) to see whether dilute hyaluronic acid might be precipitated efficiently only with denatured proteins. Recovery of hyaluronic acid with heatinactivated or fresh serum alone followed the same patterns as before but, in the mixtures, recovery was still deficient with as little as 2.5 per cent. fresh serum despite the use of enough heat-inactivated serum to allow complete precipitation of hyaluronic acid. Fresh serum thus seemed to interfere actively with the precipitation of mucin clots.

With increasing concentrations of hyaluronic acid and fixed amounts of serum (Table III), precipitation of hyaluronic acid with fresh serum gradually increased to completeness at levels about $200 \mu \mathrm{g}$. hyaluronic acid per ml., although the mucin complexes still appeared abnormal above these levels.

The effective temperature for prior heat-inactivation of the serum appeared to lie between $50^{\circ}$ and $56^{\circ} \mathrm{C}$. (Table IV, overleaf), with one discrepancy. The inhibitory effect of fresh serum had previously been found to withstand deep-freeze storage, thawing, incubation at $37^{\circ} \mathrm{C}$. for 3 days in cellcultures, and a further cycle of freezing and thawing. It was also sustained after intensive dialysis (Table $\mathrm{V}$, overleaf).

Since the activity of fresh serum could readily be detected with less than $100 \mu \mathrm{g}$. hyaluronic acid per $\mathrm{ml}$., further analyses were performed by visual comparisons with appropriate controls.

\section{CHANGES OBSERVED IMMEDIATELY AFTER} ACIDIFICATION

Acidification of hyaluronic acid and heat-inactivated serum followed the usual sequence of immediate

Table II Hyaluronic acid recovered in mucin complexes from mixtures of heat-inactivated and fresh serum

\begin{tabular}{|c|c|c|c|}
\hline \multirow[b]{2}{*}{$\begin{array}{l}\text { Hyaluronic acid added } \\
(\mu g .)\end{array}$} & \multicolumn{2}{|c|}{ Serum (per cent. $v / v)$} & \multirow[b]{2}{*}{$\begin{array}{l}\text { Hyaluronic acid recovered } \\
(\mu g .)\end{array}$} \\
\hline & Heat-inactivated & Fresh & \\
\hline $\begin{array}{l}26 \\
26 \\
26 \\
26 \\
26\end{array}$ & $\begin{array}{l}25 \cdot 0 \\
22 \cdot 5 \\
20 \cdot 0 \\
17 \cdot 5 \\
-\end{array}$ & $\begin{array}{r}- \\
2 \cdot 5 \\
5 \cdot 0 \\
7 \cdot 5 \\
25 \cdot 0\end{array}$ & $\begin{array}{r}25 \cdot 0 \\
13 \cdot 0 \\
3 \cdot 8 \\
4 \cdot 0 \\
2 \cdot 8\end{array}$ \\
\hline $\begin{array}{l}26 \\
26 \\
26 \\
26 \\
26\end{array}$ & $\begin{array}{l}50 \\
45 \\
40 \\
35 \\
-\end{array}$ & $\begin{array}{r}-5 \\
10 \\
15 \\
50\end{array}$ & $\begin{array}{r}23 \cdot 8 \\
18 \cdot 7 \\
2 \cdot 9 \\
6 \cdot 0 \\
2 \cdot 8\end{array}$ \\
\hline
\end{tabular}

Table III Mucin complexes with increasing amounts of hyaluronic acid

\begin{tabular}{|c|c|c|c|c|c|}
\hline \multirow{2}{*}{$\begin{array}{l}\text { Hyaluronic } \\
\text { acid added } \\
(\mu g .)\end{array}$} & \multirow{2}{*}{$\begin{array}{l}\text { Serum } \\
\text { concentration } \\
(\text { per cent. } v / v)\end{array}$} & \multicolumn{4}{|c|}{ Hyaluronic acid recovered from mucin complex (ug.) } \\
\hline & & $\begin{array}{l}\text { (a) With heat-inactivated } \\
\text { serum }\end{array}$ & $\begin{array}{l}\text { Appearance } \\
\text { of mucin clot }\end{array}$ & $\begin{array}{l}\text { (b) With fresh } \\
\text { serum }\end{array}$ & $\begin{array}{l}\text { Appearance of } \\
\text { mucin clot }\end{array}$ \\
\hline $\begin{array}{r}45 \\
90 \\
124 \\
248\end{array}$ & $\begin{array}{l}50 \\
50 \\
50 \\
50\end{array}$ & $\begin{array}{r}45 \\
91 \\
121 \\
247\end{array}$ & $\begin{array}{l}\text { Cohesive } \\
\text { Cohesive } \\
\text { Cohesive } \\
\text { Cohesive }\end{array}$ & $\begin{array}{r}\mathrm{Nil} \\
12 \\
70 \\
245\end{array}$ & $\begin{array}{l}\text { None } \\
\text { Cloudy } \\
\text { Cloudy } \\
\text { Turbid }\end{array}$ \\
\hline $\begin{array}{l}17 \\
34 \\
68\end{array}$ & $\begin{array}{l}20 \\
20 \\
20\end{array}$ & $\begin{array}{l}15 \\
28 \\
50\end{array}$ & $\begin{array}{l}\text { Cohesive } \\
\text { Cohesive } \\
\text { Cohesive }\end{array}$ & $\begin{array}{l}1 \\
2 \\
8\end{array}$ & $\begin{array}{l}\text { None } \\
\text { None } \\
\text { Cloudy at first, then } \\
\text { cleared }\end{array}$ \\
\hline $\begin{array}{l}137 \\
274 \\
410\end{array}$ & $\begin{array}{l}20 \\
20 \\
20\end{array}$ & $\begin{array}{l}127 \\
278 \\
416\end{array}$ & $\begin{array}{l}\text { Cohesive } \\
\text { Cohesive } \\
\text { Cohesive }\end{array}$ & $\begin{array}{l}112 \\
274 \\
427\end{array}$ & $\begin{array}{l}\text { Cloudy } \\
\text { Turbid } \\
\text { Turbid with threads }\end{array}$ \\
\hline
\end{tabular}


gelation, separation of an opaque precipitate, and contraction to a compact clot. With low concentrations of hyaluronic acid and fresh serum, the initial gelation was slight or absent. In higher concentrations, transient gelation occurred, followed by a diffuse opalescence, or transient clotting which dispersed to give opalescence or turbidity. Subsequent addition of methanol did not correct the deficiency in mucin formation, nor did the order of admixture of the three reagents. With fixed amounts of serum, the complexes formed with higher concentrations of hyaluronic acid were successively more organized, as noted in Table II.

\section{Irreversibility of effect of fresh serum}

The deficient mucin complexes formed with fresh serum were not corrected by heating at $56^{\circ} \mathrm{C}$. for 30 min. after acidification. When the mixtures were first acidified, then heat-inactivated after raising the $\mathrm{pH}$ to $7 \cdot 3$ by dialysis against Dulbecco-Vogt phosphatebuffered saline, cohesive clots still failed to appear on re-acidification.

\section{Attempts to suppress effect of fresh serum}

Heparin and chondroitin sulphate were added in considerable excess of the hyaluronic acid (Table VI, opposite).

Both these substances gave opalescence or turbidity with acetic acid, which was denser with fresh serum. Although heparin altered the mucin complexes of hyaluronic acid with heat-inactivated serum, neither heparin nor chondroitin sulphate suppressed the effect of fresh serum.

\section{Reactions at low temperature}

The foregoing observations were all made with the components at room temperature $\left(18\right.$ to $25^{\circ} \mathrm{C}$.). However, the differences between mucin complexes formed with fresh and heat-inactivated serum were repeatedly observed when the solutions were previously chilled to $4^{\circ} \mathrm{C}$. (Figure, opposite). In particular there was still an absence of immediate gelation on acidifying mixtures containing fresh serum.

\section{Effect of prior heat-inactivation upon clot formation} in abnormal synovial fluids

Synovial fluids taken from inflamed joints for diagnostic or therapeutic reasons were centrifuged to remove fibrin clots and cells. One portion of each was heat-inactivated, and the samples were diluted with one volume of $0.15 \mathrm{M} \mathrm{NaCl}$. Mucin complexes were formed with acetic acid and observed at room temperature for 30 minutes. After heat-inactivation, mucin clots were often closer to but not completely normal (Table VII, overleaf).

\section{Discussion}

When other conditions are identical, the impairment of mucin clot formation is a sensitive indication of

Table IV Effect of temperature used to heat-inactivate serum upon precipitation of hyaluronic acid

\begin{tabular}{|c|c|c|c|}
\hline \multicolumn{2}{|c|}{ Prior treatment of serum } & \multicolumn{2}{|c|}{ Hyaluronic acid ( $\mu g)}$. \\
\hline Time (min.) & Heat $\left({ }^{\circ} \mathrm{C}\right.$.) & Added & $\begin{array}{l}\text { Recovered from mucin } \\
\text { complex }\end{array}$ \\
\hline $\begin{array}{l}30 \\
30\end{array}$ & $\begin{array}{l}50 \\
56\end{array}$ & $\begin{array}{l}30 \\
30\end{array}$ & $\begin{array}{r}1 \cdot 0 \\
28.0\end{array}$ \\
\hline $\begin{array}{l}30 \\
30 \\
30 \\
30 \\
30\end{array}$ & $\begin{array}{l}38 \\
42 \\
45 \\
50 \\
56\end{array}$ & $\begin{array}{l}70 \\
70 \\
70 \\
70 \\
70\end{array}$ & $\begin{array}{r}1 \cdot 8 \\
2.9 \\
36 \cdot 0 \\
8 \cdot 0 \\
69 \cdot 0\end{array}$ \\
\hline
\end{tabular}

Table V Precipitation of hyaluronic acid with dialysed serum*

\section{Treatment of serum}

Fresh Dialysed Not dialysed

Heat-inactivated Dialysed Not dialysed
Hyaluronic acid ( $\mu g$.

\begin{tabular}{ll}
\hline Added & Recovered from mucin complex \\
\hline 20 & $2 \cdot 0$ \\
20 & $3 \cdot 4$ \\
\hline 20 & $\begin{array}{l}19 \cdot 9 \\
21 \cdot 5\end{array}$ \\
&
\end{tabular}

*At $10^{\circ} \mathrm{C}$. against 50 vols. $0 \cdot 15 \mathrm{M} \mathrm{NaCl}$, changed twice in 36 hrs.; Visking tubing 8/32. 
Table VI Effect of other polysaccharides on formation of mucin complexes

Content of solution

Appearance on acidification

A. Heat-inactivated serum ( 33 per cent. $v / v)$

with (1) hyaluronic acid (30 $\mu \mathrm{g} . / \mathrm{ml}$.)

(2) chondroitin sulphate $(330 \mu \mathrm{g} . / \mathrm{ml}$.)

(3) both

Mucin clot Opalescence in supernatant

++ , compact 0

++ , compact
+

0
\pm
\pm

B. Fresh serum ( 33 per cent. v/v)

with (1) hyaluronic acid $(30 \mu \mathrm{g} . / \mathrm{ml}$.)

(2) chondroitin sulphate $(330 \mu \mathrm{g} . / \mathrm{ml}$.)
(3) both

$\mathbf{0}$

0 (no threads or deposit)

0

$+$

$\begin{array}{ll}+++, \text { compact } & 0 \\ 0 & +++\end{array}$

(1) hyaluronic acid $(135 \mu \mathrm{g} . / \mathrm{ml}$.)

(2) heparin $(4 \mathrm{mg} . / \mathrm{ml}$.)

(3) both

++ (dense fragmented deposit)

$+t+$

D. Fresh serum (50 per cent. v/v)

with (1) hyaluronic acid (135 $\mu \mathrm{g} . / \mathrm{ml}$.)

(2) heparin (4 mg./ml.)

(3) both

\pm (few fragments)

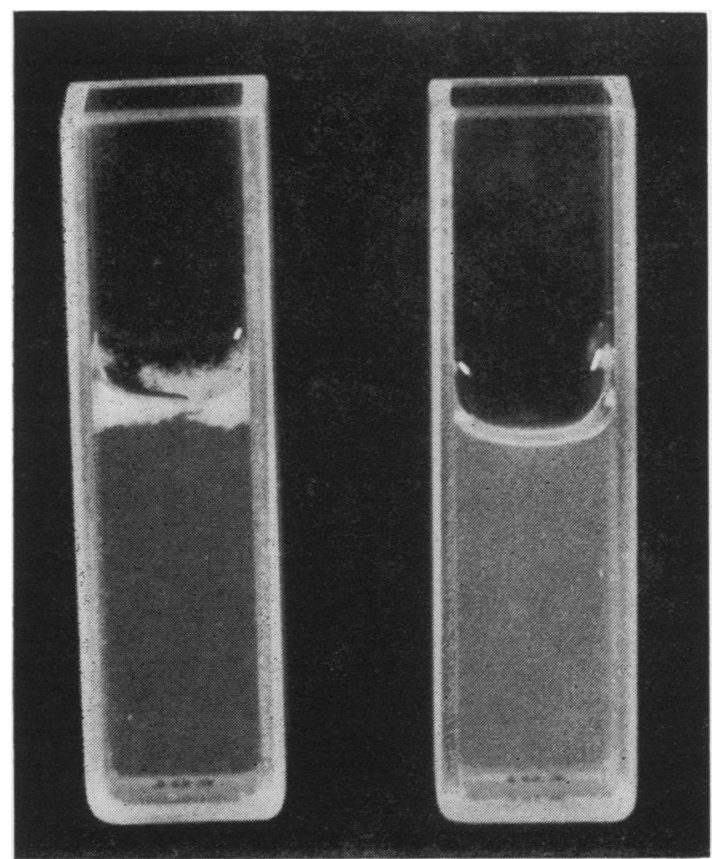

FIGURE Mucin complexes formed at $4^{\circ} \mathrm{C}$. with $75 \mu \mathrm{g}$. hyaluronic acid per $\mathrm{ml}$. and serum 50 per cent. $v / v$. Note distinct clot in heat-inactivated serum (left) and diffuse opalescence without clot in fresh serum (right).

breakdown of hyaluronic acid, and changes in parallel with the loss of viscosity (Ogston and Stanier, 1953). The effects of fresh serum described in this paper are thus consistent with a mild depolymerization of hyaluronic acid and suggest the presence of a heat-labile hyaluronidase in serum. Hyaluronidase has been demonstrated in serum by Bollet, Bonner, and Nance (1963). de Salegui and Pigman (1967) and de Salegui, Plonska, and Pigman (1967) have distinguished serum hyaluronidase activity as heat-labile, destroyed by proteases, and non-dialysable, with a low $\mathrm{pH}$ optimum and no detectable action within $22 \mathrm{~min}$. above $\mathrm{pH} \mathrm{4.9.}$ Fresh human serum reduced the viscosity of hyaluronic acid within a few minutes of acidification, though measurable $\mathrm{N}$-acetylglucosamine was liberated more slowly. Thus, in most respects, the present results with the formation of mucin complexes are explicable by heat-labile serum enzymic activity.

On the other hand, some of the evidence points in other directions. de Salegui and Pigman (1967) used a minimum ionic strength of 0.3 to avoid formation of insoluble mucin complexes which would otherwise slow the enzymic action (Pigman, personal communication), and they also found that heparin readily inhibited the enzymic effect of serum. The inhibitory effect of fresh serum on mucin formation is also notable for an impairment of immediate gelation at room temperature or $4^{\circ} \mathrm{C}$., absence of any impressive thermal dependency, and resistance to interference by considerable excess of heat-inactivated serum, heparin, or chondroitin sulphate, all of which suggest that the effect is not solely enzymic. The failure to precipitate mucin complexes by heat-inactivation after acidification can be explained by changes other than enzymic breakdown (Pigman, Hawkins, Gram- 
Table VII Effect of prior heat-inactivation of mucin clots from abnormal synovial fuids

\begin{tabular}{|c|c|c|c|c|}
\hline \multirow{2}{*}{ Diagnosis } & \multicolumn{2}{|l|}{ Synovial fluid } & \multicolumn{2}{|l|}{ Type* of mucin clot } \\
\hline & $\begin{array}{l}\text { Hyaluronic acid } \\
\text { (mg.per } \mathrm{ml} .)\end{array}$ & $\begin{array}{l}\text { Total protein } \\
\text { (mg.per ml.) }\end{array}$ & $\begin{array}{l}\text { (a) From untreated } \\
\text { fluid }\end{array}$ & $\begin{array}{l}\text { (b) From heat- } \\
\text { inactivated fluid }\end{array}$ \\
\hline Rheumatoid arthritis & $\begin{array}{r}.74 \\
1.45 \\
1.80 \\
.46 \\
1.25 \\
1.07 \\
1.57 \\
.65 \\
1.31 \\
.93 \\
.86 \\
1.37 \\
\text { N.D. } \\
\text { N.D. } \\
\text { N.D. } \\
\text { N.D. }\end{array}$ & $\begin{array}{l}38 \cdot 2 \\
17 \cdot 6 \\
35 \cdot 8 \\
40 \cdot 1 \\
44 \cdot 6 \\
37 \cdot 0 \\
24 \cdot 8 \\
44 \cdot 2 \\
32 \cdot 0 \\
43 \cdot 0 \\
46 \cdot 0 \\
37 \cdot 0 \\
\text { N.D. } \\
\text { N.D. } \\
\text { N.D. } \\
\text { N.D. }\end{array}$ & $\begin{array}{l}\text { D } \\
\text { A } \\
\text { B } \\
\text { B } \\
\text { D } \\
\text { D } \\
\text { B } \\
\text { D } \\
\text { B } \\
\text { D } \\
\text { D } \\
\text { C } \\
\text { C } \\
\text { B } \\
\text { C } \\
\text { C }\end{array}$ & $\begin{array}{l}\text { B } \\
\text { A } \\
\text { A } \\
\text { A } \\
\text { C } \\
\text { B } \\
\text { A } \\
\text { B } \\
\text { A } \\
\text { A } \\
\text { B } \\
\text { A } \\
\text { A } \\
\text { A } \\
\text { A } \\
\text { B }\end{array}$ \\
\hline $\begin{array}{l}\text { Ankylosing spondylitis with } \\
\text { peripheral arthritis }\end{array}$ & $\begin{array}{r}1 \cdot 48 \\
\cdot 80\end{array}$ & $\begin{array}{l}51 \cdot 1 \\
50 \cdot 8\end{array}$ & $\begin{array}{l}\text { C } \\
\mathbf{D}\end{array}$ & $\begin{array}{l}\mathbf{A} \\
\mathbf{B}\end{array}$ \\
\hline Gout & $1 \cdot 56$ & $27 \cdot 0$ & A & A \\
\hline Systemic lupus & $1 \cdot 20$ & $29 \cdot 2$ & $\mathbf{A}$ & $\mathbf{A}$ \\
\hline Osteoarthrosis & $1 \cdot 01$ & $21 \cdot 3$ & A & $\mathbf{A}$ \\
\hline
\end{tabular}

*A: stable cohesive clot with clear supernatant solution (see text)

B: initial clot, partly dispersing to several fragments

C: granular precipitate with few larger fragments

D: granular precipitate

ling, Rizvi, and Holley, 1960; Preston, Davies, and Ogston, 1965).

The poor precipitation of mucin complexes with fresh serum might alternatively be explained by selective bonding between hyaluronic acid and labile serum proteins with properties favouring formation of stable colloidal micelles. Many possible combinations of acid mucopolysaccharides and proteins, from serum and other sources, can precipitate like mucin complexes in appropriate conditions (Ogston, personal communication; see also Anderson, 1963), but soluble protein: polysaccharide complexes, other than those with pre-existing covalent linkages, are much more difficult to demonstrate (Noguchi, 1956). However, in conditions of physiological pH, hyaluronic acid forms soluble complexes in normal bovine synovial fluid (Ogston and Stanier, 1950) with acid-insoluble a-globulins (Curtain, 1955) and in abnormal human synovial fluid with serum inter-a trypsin inhibitor (Sandson, Hamerman, and Schwick 1965). The findings in the present experiments could be consistent with soluble complexes of hyaluronic acid with proteins containing a polar cationic structure yet a high net electronegative charge, such as might exist among the minor serum acid glycoproteins. Formation of a soluble complex initially might facilitate subsequent action of serum hyaluronidase and so ensure irreversibility.

Because of the relative amounts of hyaluronic acid and serum, and the rapidity of the reaction, measurement of the possible contribution of hyaluronidase as increased reducing sugar or freed acetylglucosamine was not possible.

Regardless of the mechanism, the effects of fresh serum suggested an explanation for the altered mucin complexes found in the fluid of inflamed joints where the protein and hyaluronic acid levels may approach some of those shown in Table III. The results of heat-inactivating such fluids indicate that this is sometimes so, but other explanations, such as lesser polymerization (Ragan and Meyer, 1949) and dilution (Hamerman and Schubert, 1962) of the hyaluronic acid, appear still to be more important

\section{Summary}

Fresh human serum impairs the size and quality of mucin clots formed by synovial cell cultures. This effect is not due to interference with secretion of hyaluronic acid, and can be reproduced by the admixture of hyaluronic acid with fresh serum in the absence of cells. Precipitation of small amounts of 
hyaluronic acid can be entirely prevented by fresh serum. The proportions recovered in the mucin precipitate increase to completeness as the hyaluronate concentration approaches 200 to $300 \mu \mathrm{g}$. per ml., depending on the amount of fresh serum. Above this range, recovery is complete, but the appearance of the mucin clots remains abnormal.

Further studies have indicated that the inhibitory effect is due to a reaction between hyaluronic acid and a heat-labile nondialysable component of serum. It does not appear to be entirely attributable to hyaluronidase activity in the serum because it is in part immediate, it is not counteracted by excess amounts of heat-inactivated serum, heparin, or, chondroitin sulphate, and it can be demonstrated at $4^{\circ} \mathrm{C}$.

Abnormal mucin clots from pathological synovial fluids can be partly restored towards a normal appearance by prior heat-inactivation.

We are grateful to Drs. K. D. Muirden and Roderick Strang for samples of synovial fluid; to Professors E. G. L. Bywaters and A. G. Ogston for background information, and to Professor Bywaters for review of the manuscript.

The work was made possible by grants from the Arthritis and Rheumatism Council for Research in Great Britain and the Commonwealth, the Australian Rheumatism Council, and the National Health and Medical Research Council of Australia.

\section{References}

ANDERSON, A. J. (1963) Biochem. J., 88, 460 (The formation of chondro-mucoprotein-fibrinogen and chondromucoprotein $\beta$-lipoprotein complexes).

Bollet, A. J., BonNer, W. M., JR., AND NANCE, J. L. (1963) J. biol. Chem., 238, 3522 (The presence of hyaluronidase in various mammalian tissues).

Clarris, B. J., and Fraser, J. R. E. (1968) Exp. Cell Res., 49, 181 (On the pericellular zone of some mammalian cell in vitro).

CurTaIN, C. C. (1955) Biochem. J., 61, 688 (The nature of the protein in the hyaluronic complex of bovine synovial fluid).

De salegui, M., And Pigman, W. (1967) Arch. Biochem. Biophys., 120, 60 (The existence of an acid-active hyaluronidase in serum).

-, Plonska, H., AND Pigman, W. (1967) Ibid., 121, 548 (A comparison of serum and testicular hyaluronidase).

Fraser, J. R. E., Harris, G. S., AND Clarris, B. J. (1969) Ann. rheum. Dis., 28, 419 (Influence of serum on secretion of hyaluronic acid by synovial cells).

Hamerman, D., AND Schubert, M. (1962) Amer. J. Med., 33, 555 (Diarthrodial joints, an essay).

NoGUCHI, H. (1956) Biochim. biophys. Acta, 22, 459 (Interactions of proteins with polymeric materials).

Ogston, A. G., and StaniER, J. E. (1950) Biochem. J., 46, 364 (On the state of hyaluronic acid in synovial fluid). , (1953) J. Physiol. (Lond.), 119, 253 (Some effects of hyaluronidase on the hyaluronic acid of ox synovial fluid, and their bearing on the investigation of pathological fluids).

Pigman, W., Hawkins, W., Gramling, E., Rizvi, S., and Holley, H. L. (1960) Arch. Biochem. Biophys., 89, 184 (Factors affecting the viscosity of hyaluronic acid and synovial fluid).

Preston, B. N., Davies, M., and Ogston, A. G. (1965) Biochem. J., 96, 449 (The composition and physicochemical properties of hyaluronic acids prepared from ox synovial fluid and from a case of mesothelioma).

Ragan, C., AND Meyer, K. (1949) J. clin. Invest., 28, 56 (The hyaluronic acid of synovial fluid in rheumatoid arthritis).

Robertson, W. van B., Ropes, M. W., ANd BaUer, W. (1940) J. biol. Chem., 133, 261 (Mucinase; a bacterial enzyme which hydrolyzes synovial fluid mucin and other mucins).

Sandson, J., Hamerman, D., And Schwick, G. (1965) Trans. Ass. Amer. Phycns, 78, 304 (Altered properties of pathological hyaluronate due to a bound inter-alpha trypsin inhibitor). 